Open Access

\title{
A departure for returning to sabha: a study of koan practice of silence
}

Jea Sophia Oh

Correspondence: joh@wcupa.edu West Chester University of Pennsylvania, 700 S High St. AND 108D, West Chester, PA 19383, USA

\begin{abstract}
This paper deals with koan practice of silence through analyzing the Korean Zen Buddhist film, Why Has Boddhidharma Left for the East? (Bae, Yong-Kyun, Why Has Bodhidharma Left for the East? 1989). This paper follows Kibong's path along with the Buddha's journey of 1) departure, 2) journey in the middle way, and 3) returning with a particular focus on koan practice of silence as the transformative element of enlightenment. Analyzing silence throughout the film, this paper studies the Seon Buddhist lifestyle in an aesthetic way and finds a philosophical understanding of interdependency of samsara and nirvana. Silence is a crucial element of koan. Koan is, indeed, not to be answered, but to be practiced through one's life.
\end{abstract}

"To the disciple who asked about the Truth, without a word he showed a flower."

Koan practice is a well-known pedagogy of Chan Buddhist School. Chan is known as Zen in Japan and Seon (禪, meditation) in Korea. ${ }^{2}$ Korean Seon Buddhism is a school of Mahayana Buddhism, which was transmitted to Korea from China in the $8^{\text {th }}$ century during the Silla dynasty (57BCE $\sim 935 \mathrm{ACE})$. The origin of the Chinese Chan School can be traced to the legendary monk Bodhidharma in the $6^{\text {th }}$ century who transmitted Chan from Southern India to China. Zen Buddhism was transmitted to Japan in the $12^{\text {th }}$ century from China. Korean Seon Buddhism received its most significant impetus and consolidation from the Goryeo monk Jinul (知訥) (1158-1210), who established a reform movement and introduced koan practice to Korea. The Korean Seon Buddhist film, Why Has Bodhidharma Left for the East?, is unfolded throughout the young Seon practitioner, Kibong's departure (出家, chulga in Korean) and koan practice (隨行, soohang in Korean) focusing on two riddles given by his master, Hyegok, "When the full moon takes over your heart, where does my true-self go?" and taking care of his master's corpse after his master's passing. To some extent, Kibong's journey to enlightenment resonates with the prince Siddharta's great departure, long yogic practice, and returning back to the world (娑婆, sabha). Koan plays the key role of the process of enlightenment in Seon Buddhism. Indeed, silence is portrayed as an essential element of the Seon Buddhist life. In the film, Why Has Bodhidharma Left for the East?, koan is practiced via silence (黙言修行, mookunsoohang in Korean). ${ }^{3}$

This paper follows Kibong's path of 1) departure, 2) journey in the middle way, and 3) returning with a particular focus on koan practice of silence as the transformative

(c) The Author(s). 2017 Open Access This article is distributed under the terms of the Creative Commons Attribution 4.0 International License (http://creativecommons.org/licenses/by/4.0/), which permits unrestricted use, distribution, and reproduction in any medium, provided you give appropriate credit to the original author(s) and the source, provide a link to the Creative Commons license, and indicate if changes were made. 
element of enlightenment. Nonetheless, each step embraces a different quality of silence which seems to be vulnerable to criticism in the neo-Confucian Korean society and may conflict with its set of promoted virtues. Perhaps, to outsiders, departure can be seen as abandonment of family and silence can be seen as severance of communication. Beyond these seemingly negative processes and practices of Seon Buddhism, this paper tries to answer the great koan, "Why has Bodhidharma left for the East?" In order to practice koan, silence is a crucial element which transforms samsara into nirvana. Analyzing silence throughout the film, this paper studies the Seon Buddhist lifestyle in an aesthetic way and finds a philosophical understanding of interdependency of samsara and nirvana. Koan is, indeed, not to be answered out, but to be practiced out through one's life. Thus, a koan practice of silence is endless self-emptying in the middle way. A departure is, therefore, a returning. Bodhidharma returned to the world to share his realization and compassion with people, to become one with nature.

Quiet is his wisdom,

Calm his emotion, Serene and firm his reasoning.

His will has departed. -from The Lotus Sutra - ${ }^{4}$

\section{A silent departure (出家)/A detached self}

Hajin: Why have we all left the world?

Kibong: It's because in the world, there is no peace nor freedom. I was destined to take care of my family. It is such an immoral act to take a departure for myself. However, I was thirsty for the freedom of the soul. I couldn't do two things at a time. I had to leave the narrow path that was covered by sufferings like dust to find myself again in an open field. When I decided to leave the world, morality and family love seemed to be chains that I had to break along with the worldly desires and pleasures. I must reach enlightenment and find the way of the great freedom. ${ }^{5}$

The film, Why Has Bodhidharma Left for the East?, introduces Kibong as a man who has become a monk to escape his familial obligations to his blind mother and his sister and shows his dilemma of attachment to the individualized quest for enlightenment. ${ }^{6}$ In the film, Kibong's departure seems to be somewhat similar to the typical Buddhist motivations of departure. One can be compelled to become a monk by some burning questions such as "Why do we live?" By awakening, one would know him/ herself and find the essence of life. In some cases, one becomes a monk because of some difficulties of his/her life such as poverty and distress. ${ }^{7}$ In the case of Kibong, a complex set of factors motivated him to leave his family. Although Kibong was responsible for his blind mother and younger sister in a fatherless family, he was struck by a burning question, "who am I truly?" He first fled from his worldly circumstances and took a vow of silence. However, his silent departure would seem to be immoral according to the conventional Confucian expectations regarding family obligations and filial virtues.

Korea is a neo-Confucian society. For centuries in Korea, Confucianism has meant a system of education, ritual ceremony and civil administration as first expressed by 
Confucius in his writings. Confucian concepts of social harmony and moral precepts permeated the intellectual life of the old East Asia and played a pivotal role in molding the Korean culture as we know it today. After so many centuries of indoctrination in these tenets, however, Koreans can hardly be said to have discarded the customs, habits and thought patterns derived from the old system. It is easy to see the influence of Confucianism on Koreans today. Older people are still very much respected. Among a group of friends or co-workers, the oldest person is expected to pay in a restaurant while the youngest is expected to serve the food. Still today, most young Koreans can imagine no greater trespass than openly defying their parents. ${ }^{8}$

In this regard, Kibong's silent departure can be seen against filial piety (孝, xiao) which is the fundamental virtue of other virtues by Confucius. On the other hand, Kibong's departure might be a good model of detachment in Buddhism. Detachment is a central concept in Seon Buddhism. One of the most important technical Chinese terms for detachment is "wú niàn" (無念), which literally means "no thought." This does not signify the literal absence of thought, but rather the state of being "unstained" (不染, bù rán) by thought. Therefore, "detachment" is being detached from one's thoughts. It is to separate oneself from one's own thoughts and opinions in detail as to not be harmed mentally and emotionally by them. According to the basic teaching of the Buddha, worldly sufferings (苦, duhkha) result from attaching oneself to what one does not have or even what one cannot have along with inevitable existential sufferings such as aging, sickness, and death. Indeed, the deepest meaning of duhkha is the inability to live well when at odds with the truth of interdependent arising. Thus, duhkha has a deeper meaning of unsatisfactoriness. ${ }^{9}$

In the film, Kibong was introduced as a discontented young man who comes to the mountain hermitage to search for his true self. His Confucian virtue as a head of the household seems to be disharmonized with his own possibilities of self-realization. In his case, departure is detachment from his blind elderly mother and underage sister. He suffers from the family pressures of taking care of his blind mother. He has a strong desire to escape from reality and to chase after personal freedom. Therefore, he chooses to leave the world and seek after enlightenment. By doing so, he has to empty his inner world and break the ties with his family. From a Confucian point of view, he deserves criticism for turning away from his filial responsibility. The irony is that, when he becomes a monk, he is sent to a remote mountain to take care of a sick Seon Master, Hyegok, and a baby orphan brother, Haejin. His departure from his family caused him to have another set of relationships. That is to say, there will be no way one can be completely detached from human relationships, but we all probably have to live an endless karma of attachment and detachment through continual practices of emptying and filling. Although Kibong ordains with the hope that he can achieve liberation and enlightenment by cutting off all attachments to his previous life, he cannot avoid this karmic facticity of relationships.

Then, is Kibong's departure a form of escapism or a denial of reality? Kibong has departed from his duhkha, unsatisfactoriness, and silently practiced out his koan with endless guilt and self-blame. Kibong's central dilemma and problem of the self is that he presumes that freedom and escape are the same thing. Kibong's suffering is resultant from his unpeaceful mind. He is in fact overly attached to the distinction between freedom and entrapment, nirvana and samsara as his master Hyegok replies, "It is because people do not have enough heart to hold all the things in 
the world. In fact, they have enough heart but it is full of the idea of the self." Hyegok gave Kibong a koan and ordered him to practice a silent meditation, "When the full moon arises in your heart, where does the master of my self go?"10

Departure, getting rid of the link with families, is a necessary process for people who want to attain enlightenment. How about the "Great Departure" of Siddhartha Gautama? While Kibong departed from his suffering, the Prince Siddhartha has departed from the palace in order to eliminate suffering in the world. The Great Departure of the Buddha was neither escapism nor hibernation. "The Prince left the palace through the eastern gate and went for the forest." When Siddhartha decided to leave the palace, he heard that his wife delivered his son. He named his son, Rāhula, which means "obstacle." What a name! What kind of father can name his first son obstacle? From a Confucian point of view, there is no higher virtue than being loyal to one's family. Both Kibong and Siddhartha left their parents and families. It can be considered a most unethical act in the Korean Neo-Confucian society. Most of all, abandoning parents and children is the worst. However, is there anyone who has no obstacle when $\mathrm{s} /$ he tries to accomplish a greater self-realization? A departure of a Buddhist monk is called chulga in Korean (出家) which literally means "leaving home." Thus, the first and inevitable act for chulga (出家) is actually "detachment" which is the practice of dan in Korean (斷, the practice of severing/cutting off something attached). Departure is, therefore, detachment. The great departure is neither denial of reality nor facing away from the world but it is dan (斷) to realize a true self. Without words, the Buddha, Bodhidharma, and Kibong left alone like a rhinoceros.

Cutting off (斷, dan) the householder's marks,

like a kovilara tree that has shed its leaves, the prudent one,

cutting (斷, dan) all household ties,

wander alone like a rhinoceros.

Abandoning offspring, spouse,

father, mother,

riches, grain, relatives,

and sensual pleasures altogether,

wander alone like a rhinoceros.

Unstartled, like a lion at sounds.

Unsnared, like the wind in a net.

Unsmeared, like a lotus in water:

wander alone like a rhinoceros. - from The Rhinoceros Sutra- ${ }^{11}$

\section{A journey in the middle way/A muted self}

Prince Siddhartha wanted to see his son Rähula once before leaving. He opened the door of his wife's room. A scented candle was burning in the room. Rähula's mother was asleep in the beautiful flowery bed with her baby. Prince Siddhartha was looking at them and thinking, "If I hold Rähula, my wife will wake up and the baby will cry. Then, it will distract my leaving. I will return and see them again after enlightenment." He quietly sneaked out of the palace. ${ }^{12}$ 
The Buddha's departure was a tough one. What a poignant story! As a human father, he couldn't even hold his first baby who was just born. Instead, he left without words. The Buddha's silence at his departure can be recognized as an extreme case of dan (斷, cutting off) which is similar to Kibong's silence, when he visited his house to check on his blind mother after his departure. Unlike his expectation of freedom after his departure, he was not free at all but suffered from the guilt of abandoning his family. He cut off his affections and responsibility for his family. Instead of his old blind mother and a younger sister, he now has an old sick master and a little brother. When one tie is untangled or detached, another one will be started onwhich is the karmic causation. Because of his attachment with his old master, Kibong broke his koan and came down the mountain to the marketplace to buy some medicines for curing his master's sickness. At the same time, he also went back to his home to visit his blind mother. What a poignant scene to watch, he entered his mother's home but could not say a word. A blind mother and a mute son, two suffering people in the world were unable to communicate with one another and yet created a most profound and powerful interaction via silence. In this moment, the silence works as both a form of meditation as well as a form of communication. His mother could sense that her lost son is present and called out for him. He was totally muted since he vowed to the silent koan. He helped his mother to find her pills with no word and quietly stepped out like the Buddha did to his wife and the baby. He was able to meditate on his decision and the silence allowed a blind mother and a mute son to achieve a form of closure.

Siddhartha, instead, told himself, "I will return after enlightenment." Before becoming the "Enlightened One," Siddhartha saw four signs that set him on his path towards being enlightened. The signs Siddhartha saw were: an old man, a sick man, a dead man, and a recluse, or a man who has "gone forth." These signs were the first to introduce Siddhartha to pain and suffering which he later deemed to be "duhkha." Duhkha was this pain that the human condition obtains from both internal and external sources. It can come from natural and artificial sources. However, after the fourth sign, Siddhartha saw that duhkha could be eliminated from the lives of people, that could be the reason why Bodhidharma has left for the East as the film says via a young monk's confession, "the great departure is, therefore, the great returning."

After leaving his life of comfort behind, the Buddha sought out spiritual leaders and practitioners whom may help him obtain the same inner peace that the man has "gone forth" possessed. It was in these studies and travels that the Buddha realized that the method to claim this peace was through the "Middle Way." The Middle Way was a method of, "knowing how to focus his consciousness and how to observe his feelings, and no longer be afraid of the happiness that is not coupled with evil and depravity, he practiced a form of reflective meditation in which he investigated the arising of suffering in life, its conditions, and the way to remove these conditions." ${ }^{13}$ A Korean Buddhist scholar Jin Y. Park explains the Buddha's Middle Way in terms of mutual dependency of the constituents of a being: "Existence is conditional and dependent upon various conditions in each and every moment, which makes existence possible. Existence is a result of a combination of various conditions. This interdependency of things is what the Buddha calls the Middle Path." 14 By eliminating duhkha in one's life, through the practice of the Middle Way, by living the Buddha's teachings, one can eventually find nirvana. 
In order to focus on enlightening the self, meditation is the practice of emptying one's mind of idle thoughts. In the film we can see the Buddhist monks meditate in silence while sometimes accompanied by the beating of the moktak (木鐸, the wooden drum). Meditation is very much a disciplined kind of silence in which the silence of the mind brings tranquility and enlightenment. Silence in this film is not just scenes when there is no sound, it has a purpose. This purpose is not to just make the tone quiet but to stress dramatic effect. This dramatic effect is accomplished on many levels. On some levels, we are brought to the magnificence of nature and the natural beauties the world has to offer. On other levels, the silence builds tension and alerts us to a pending explosion of action or emotion. On some occasions, the silence is used to bring the audience and the actors to a meditative, peaceful, state of being. Yet, in some instances, we find the silence acting as a method of clearing the way, and used as a transition from one scene into another. But the ultimate purpose for silence, as has been taught by the Buddha himself, is that silence leads to truth, which in turn, leads to the Middle Way. In the Middle Way of interdependency and interconnectedness, roughly speaking, samsara is nirvana, indeed! Like a lotus in the muddy water, the Eternal Bliss can be realized through sufferings.

"Did you find the answer of your koan?" "Why don't you realize that where you stood today is the Land of Perfect Bliss [Sukhāvatī]?" "When the moon takes over your heart, where does the master of my self go?”15

\section{The great returning/One with nature}

Barechested, barefooted, he comes into the market place.

Mudded and dust-covered, how broadly he grins!

Without recourse to mystic powers,

Withered trees he swiftly brings to bloom. ${ }^{16}$

In order to practice out his first koan, "When the moon takes over your heart, where does the master of my self go?," Kibong has attempted many harsh ways of intensive meditation and engaging in the extreme ascetic practices of meditating with a stone on his head and even forcing his body to remain still upon a rock in the midst of a raging river. Nonetheless, like the Buddha realized that two extremes of ascetic practice and yogic practice couldn't be the ultimate way of enlightenment, Kibong discovers that such extremes only bring more suffering. There is almost no way he could get out of attachment to the world even in the monastery. Thus, the master gave him a final koan, "When I pass away, please return my body to the source (nature)." Kibong continues to falter in his practicing until given the final koan this one comes in the form of cremating the master's body and scattering its ashes within a day after the master's passing. By observing his master's passing Kibong must learn what his master teaches, "to leave is to arrive; to arrive is to leave," as a Korean Buddhist scholar Sharon A. Suh argues that enlightenment and liberation cannot be attained through escape from worldly entanglements. ${ }^{17}$ Accepting the fact that the master has passed away and letting him go through the difficult task of cremating his body, collecting his bones through the ashes, grinding his bones, and scattering his bone powder to feed 
fishes and birds, to fertilize trees and flowers, to dust out in the air, Kibong finally realized the fact that "leaving is returning." Suh is right when she writes, "Death can sometimes be the most effective dharma teacher. One does not have to learn how to magically overcome death or transcend this worldly life in order to experience nirvana." ${ }^{18}$ Separation from loved ones at death is such a tough lesson in life that duhkha is an inevitable condition of life for spiritual growth and discipline, the very ground of nirvana.

Kibong took a departure from his house to the temple due to the quest for true self. The question, "Who am I?," is a most fundamental question for Seon practitioners. The point of Seon is to realize our true nature, our self-nature. Meditation is a most intimate way to deal with the question. ${ }^{19}$ Through practicing out the second koan, Kibong learned that the self is none other than a participant of the entire world, being one with nature.

The narration of the film when he returned to the temple from the marketplace tells a truth of the Buddha's teaching:

I became a hermit to free myself from the dust and the dirt of the world, looking for perfection. But I realized that it was impossible without loving the garbage and the dust of the world, even life's passions. If it's easy to fight against reality and fate, it is difficult to love them. What a beautiful world when you know how to love it! The great departure is, therefore, the great returning. ${ }^{20}$

When he returned to the temple, the master monk scolded and taught him, "For you, nirvana and samsara are two different worlds. But the marketplace you stood in sabha (梁婆, the mundane world) is the actual place of nirvana." Kibong asked the master, "If you pass away, whom should I ask questions?" The master told, "To the air, trees, mountains, and rivers. My flesh and blood will be scattered and reincarnated as the stars in the sky and dust in the wind." The Seon master, Hyegok taught Kibong the truth via his silent death. Silence is a path to attain enlightenment. The most powerful use of "silence" in this film comes after the cremation ceremony of the master; where silence is used to create a visceral response. After some initial challenges getting the pyre to light, Kibong sits in silence as his master is returned to the earth. This part in the film, the silence gives the audience a view into the spirit of Kibong. What is normally peaceful and tranquil, the silence seems almost chaotic and deceptive. The silence becomes uncomfortable. We almost want to hear a scream or a cry. But we never get that noise. This indicates to us that the silence is emotional in nature. But as silence is a meditative tool and a relaxing mechanism, we begin to understand its purpose.

As a part of the Buddha's teachings, silence is one of the most powerful tools in obtaining clarity and reaching nirvana. As a part of the Four Noble Truths, the fourth to be specific, the Buddha introduced the world to the Noble Eightfold Path. Within this Noble Path, we have "Right Speech." Right Speech means knowing the time and place for which certain talk is appropriate, implying that sometimes one should maintain "noble silence." ${ }^{21}$ This is based upon a negative golden rule, "If you don't want to get hurt, do not hurt others." Therefore, silence is actually a way of practicing 'nondoing (無爲, wu-wei).' As Hyegok taught Kibong, "If you shut your mouth, you can get the truth of nirvana," this noble silence is crucial in understanding truth. The Buddha expresses this in an interaction he once had with a philosopher: 
A philosopher once visited the Buddha and asked him: "Without words, without the wordless, will you tell me the truth?" The Buddha kept silence. After a while the philosopher rose up gently, made a solemn bow and thanked the Buddha saying: "With your loving kindness, I have cleared away all my delusions and entered the true path." When the philosopher had left, Ananda, a senior disciple of the Buddha, enquired: "O, Blessed one, what hath this philosopher attained?" The Buddha replied: "A good horse runs even at the shadow of the whip!"

Hajin: Brother, Where are you going?

Kibong answers no word but looks at the east side and left.

The baby monk Hajin didn't cry after his master passed away but silently burned his master's belongings as if he copied what his brother did for his master and meditated in the master's room. He silently let his brother Kibong go for his second departure to the East. Kibong's second departure symbolizes that nirvana is not a permanent event 'once and for all' but actually a continual process within samsara in the world sabha. "Why Has Bodhidharma Left for the East?" "Well, because enlightenment is indeed a continual becoming and dynamic self-emptying." When we realize the fact that the great departure is indeed the great returning, we can and should live in the world of samsara but in new and nirvanic ways as the Buddha lived. Koan for Seon practitioners is given guidance in realizing the Way and embodying wisdom in their own lives. ${ }^{23}$ When an $h w a d u^{24}$ is given to a practitioner, one must trust one's own wisdom and the Buddha-nature and not look for an answer outside oneself. ${ }^{25}$ As koan is not to be discursively answered but to be existentially practiced, nirvana might be nothing other than an endless practice of enlightening and becoming with a continual rhythm of emptying and filling. The process of self-realization empties only the moment's selfactualization not into nothingness but into one with nature in the world sabha, "the community of all becoming." ${ }^{26}$

Coming, going, seeing hearing: this marvelous thing!

Huge, it covers the sky,

Small, it enters a speck of dust,

Bright, like sun and moon,

Dark, like a lacquer barrel.

Mountains, rivers, great earth:

They are but this thing.

To speak of being or nonbeing

Is the dispute of Shaolin.

Avoid such useless words! ${ }^{27}$ (The Poem, This Thing in Women in Korean Zen)

\section{Endnotes}

${ }^{1}$ The Korean Seon Buddhist film, Why Has Bodhidharma Left for the East? begins with the well-known koan, "To the disciple who asked about the Truth, without a word he showed a flower," in The Flower Sermon. "When Shakyamuni Buddha was at Mount Grdhrakuta [Vulture Peak], he held out a flower to his listeners. Everyone was silent. 
Only Maha-Kashayapa broke into a broad smile. Sekida, Katsuki. trans. 1977. Two Zen Classics: the Mumonkan \& Hekiganroku. New York: Weatherhill.

${ }^{2}$ Seon (禪) is known for its stress on meditation, monasticism, and asceticism. Seon practitioners pursue extremely minimalist lifestyles. Many Korean monks have few ?A3B2 show \$132\#?>personal possessions and sometimes cut off all relations with the outside world. Some are near mendicants traveling from temple to temple practicing meditation. The hermit-recluse life is common among monks to whom meditation practice is considered of paramount importance.

${ }^{3}$ Silent meditation is also known through the $M u$ (無) koan. $M u$ (無) is a realm beyond words or concepts that opens up with the stilling of the discursive mind. Seon Practitioners are invited to plunge deeply into $M u$. Habito, Rubin L.F. 2013. Zen and the Spiritual Exercises. New York: Orbis Books. 14.

${ }^{4}$ The Lotus Sutra. 2008. Translated by Gene Reeves. Boston: Wisdom Publications. 26.

${ }^{5}$ Bae Yong-Kyun's Why Has Bodhidharma Left for the East? A Milestone Film \& Video Release (1989).

${ }^{6}$ Suh, Sharon A. 2015. Silver Screen Buddha: Buddhism in Asian and Western Film. London: Bloomsbury, 26.

${ }^{7}$ Batchelor, Martin, and Son Gyong Sunim. 2006. Women in Korean Zen: Lives and Practices. Syracuse: Syracuse University Press, xix.

${ }^{8}$ Oh, Jea Sophia. "My Father- Filial Piety (孝, xiao) and a Daughter's Love," Jesus, Jazz, Buddhism. May 2011. http://www.jesusjazzbuddhism.org/my-father-5050048736.html.

${ }^{9}$ Koller, John M. 2012. Asian Philosophies $6^{\text {th }}$ edition. Upper Saddle River: Pearson. 44. C.

${ }^{10}$ Bae Yong-Kyun's Why Has Bodhidharma Left for the East? A Milestone Film \& Video Release (1989).

${ }^{11}$ The Rhinoceros Sutra is a very early Buddhist text advocating the merit of solitary asceticism for pursuing enlightenment.

${ }^{12}$ Park, Sooil ed. 1991. "Bumryun Lectures." in Ingan Buddha [Human Buddha]. Seoul: Jungto. 167.

${ }^{13}$ Koller, 41.

${ }^{14}$ Park, Jin Y. "Naming the Unnameable," Jin Y. Park ed. 2006. Buddhisms and Deconstructions. Lanham: Rowman \& Littlefield Publishes, 10.

${ }^{15}$ In the film, the master scolded Kibong for his return from the marketplace for getting his medicine even by breaking his koan. One of the strongest examples where silence is used happens when Kibong heads to the city to beg for offerings. He finds himself in the middle of a noisy and busy market. The hustle and bustle of the world becomes an overwhelming audible sensation. The monk is hitting his wooden drum (moktak) in a monotonic pattern. As he does this the sounds slowly fade away. Here the young monk enters into a meditative state and takes the audience with him at the same time. This state creates a peaceful moment in an otherwise chaotic setting.

${ }^{16}$ The verse is taken from The Three Pillars of Zen by the twelfth-century Chinese Zen master, Kuo-an, that describes the Zen way of enlightenment. Koller, 295.

${ }^{17}$ Suh, 115.

${ }^{18}$ Ibid., 122.

${ }^{19}$ Habito, 173.

${ }^{20}$ This is a narration of the film on the way Kibong returned back from the marketplace to the temple again. 
${ }^{21}$ Koller, 50.

${ }^{22}$ This is a famous parable of the Buddha. Author unknown. Edited by Paul Reps. 1985. Zen Flesh, Zen Bones.

${ }^{23}$ Habito, 13.

${ }^{24} \mathrm{Hwadu}$ (話頭, Korean: hwadu, Japanese: wato) is a form of Seon meditation common in the teachings of Chan Buddhism and Korean Seon. and Rinzai Zen. Hwadu can be translated as point beyond which speech exhausts itself. Hwadu is the central point of a koan that is singled out as a topic of meditation. Batchelor, 118.

${ }^{25}$ Ibid., 19.

${ }^{26}$ Keller, Catherine. "Scoop up the Water and the Moon Is in Your Hands: On Feminist Theology and Dynamic Self-Emptying," in The Emptying God: A BuddhistJewish-Christian Conversation. Edited by John B. Cobb, Jr. and Christopher Ives. 1990. New York: Orbis Books. 114.

${ }^{27}$ Batchelor, 112.

\section{Acknowledgement}

I acknowledge that I have read, understand, and agree to the policies of submission.

\section{Competing interests}

This paper is an interdisciplinary study of religion and film. Since this paper is a film analysis, it is really helpful to non-Buddhist readers to learn a crucial Buddhist concept of koan in Zen by following the aesthetic analysis of the plot of the film which is compared with Buddha's process of enlightenment. Also, the enlightening process is indeed existential living, therefore, koan is an existential question(s) to be practiced and lived. This paper is not explicitly a paper of Buddhist studies but interdisciplinary, comparative, philosophical analysis which anyone can enjoy and learn.

\section{Publisher's Note}

Springer Nature remains neutral with regard to jurisdictional claims in published maps and institutional affiliations.

Received: 10 August 2016 Accepted: 5 May 2017

Published online: 19 May 2017

\section{References}

Bae, Yong-Kyun directed. Why Has Bodhidharma Left for the East? 1989. Seoul: A Milestone Film \& Video Release. Batchelor, Martin, and Son Gyong Sunim. 2006. Women in Korean Zen: Lives and Practices. Syracuse: Syracuse University Press. Habito, Rubin L.F. 2013. Zen and the Spiritual Exercises. New York: Orbis Books.

Koller, John M. 2012. Asian Philosophies, 6th ed. Upper Saddle River: Pearson.

Oh, Jea Sophia. "My Father- Filial Piety (孝, xiao) and a Daughter's Love," Jesus, Jazz, Buddhism. May 2011. http://www. jesusjazzbuddhism.org/my-father-5050048736.html.

Park, Jin Y. "Naming the Unnamable," Jin Y. Park ed. 2006. Buddhisms and Deconstructions. Lanham: Rowman \& Littlefield Publishers

Reeves, Gene trans. The Lotus Sutra. 2008. Boston: Wisdom Publications.

Sekida, Katsuki (ed.). 1977. Two Zen Classics: the Mumonkan \& Hekiganroku. New York: Weatherhill.

Suh, Sharon A. 2015. Silver Screen Buddha: Buddhism in Asian and Western Film. London: Bloomsbury.

\section{Submit your manuscript to a SpringerOpen ${ }^{\circ}$ journal and benefit from:}

- Convenient online submission

- Rigorous peer review

- Open access: articles freely available online

- High visibility within the field

- Retaining the copyright to your article 